IJTI (International Journal Of Transportation And Infrastructure)

Available Online @ http://jumal.na rota ma.ac.id/index.php/ijti ISSN : 2597-4769 (ONUNE) ISSN : 2597-4734 (CETAK)

\title{
BEST RAW MATERIAL STORAGE METHOD FOR KEEPING QUALITY OF FOOD PRODUCTION
}

\author{
Vincent Audi Santoso \\ Narotama University, Surabaya, Indonesia \\ e-mail:v_audi@yahoo.com
}

\begin{abstract}
Food is a basic human need that is needed at all times and requires good and proper management in order to benefit the body. According to WHO, the intended food is: "Food include all substances, whether in a natural state or in a manufactured or preparedform, wich are part of human diet."These food restrictions do not include water, medicines and substances needed for medicinal purposes.
\end{abstract}

Keyword : Material Storage, Food Production, Raw Material

\section{INTRODUCTION}

The food consumed should meet the criteria that the food is worth eating and does not cause disease, including:

1. Be in the desired degree of maturity

2. Free from the pollution at each stage of production and subsequent handling.

3. Free from the undesirable physical, chemical changes, as a result of enzymatic influences, microbial activities, rodents, insects, parasites and pressure, cooking and drying damage.

4. Free from microorganisms and parasites that cause food-borne diseases (food borne illness).

\section{METHOD}

1. Method of storing raw materials to the quality of food production.

2. Method of storage, Production Quality, Hygiene Personal, Hygiene Food, Hygiene Equipment. and Kitchen Hygiene.

\section{DISCUSSION}

\section{A. Hygiene and Sanitation}

Understanding the hygiene according to Seples is a health effort by maintaining and protecting the cleanliness of individual subjects. For example, washing hands to protect the hand hygiene, washing dishes to protect the 
IJTI (International Journal Of Transportation And Infrastruct ure)

dishes cleanliness, dispose of damaged food parts to protect whole food integrity.

Food sanitation is one of the prevention efforts that emphasizes the activities and actions necessary to free the food and drink from all dangers that can disturb or cook health, from before the food is produced, during processing, storage, transportation, until the time when food and drink are ready to be consumed to the public or consumers. Food sanitation aims to ensure the safety and purity of food, prevent consumers from disease, prevent the sale of food that will harm the buyer. reduce damage / waste of food. In food management there are 6 principles that must be noticed namely:

\section{The state of food}

All food items need to be physically attentive and their freshness guaranteed, especially decaying or damaged food ingredients such as meat, fish, milk, eggs, canned food, fruit, and so on. Good food is sometimes not easy to find, because the network of food travels that long and through a wide trading network. One of the efforts to get good foodstuffs is to avoid the use of foodstuffs derived from the uncluar sources is not clear (wild) because it is less reliable in quality.

\section{How to store food}

Not all food items are readily consumed by the community. Foods that are not processed, especially for catering and hospital food maintenance need good storage, given the nature of different foodstuffs and can rot, so the quality can be maintained. The storage methods that qualify for food sanitation are as follows:

1. Storage must be done in a special place (warehouse) that is clean and qualified

2. Goods are easy to pick up, do not give insects or rats a chance to nest, avoid flies and rotten or damaged products to be stored at cold temperatures.

\section{Processing}

In the process / way of food processing there are three things to get attention That is:

\section{Food processing place}

Food processing is a place where food is processed, the good processing place is often called the kitchen. Kitchen has an important role in the process of food processing, therefore the cleanliness of the kitchen and the surrounding environment 
must always be awake and cared for. A good kitchen should meet sanitary requirements.

\section{Food Processing / Food Handlers}

Food handlers according to DepKes RI (2006) are people who are directly related to food and equipment starting from the preparation stage, cleaning, transportation processing until presentation. In the process of food processing, the role of food handlers is very big role. These food handlers have an opportunity to transmit the disease. Many infections are transmitted through food handlers, among others, Staphylococcus aureus is transmitted through the nose and throat, Clostridium perfringens germ, Streptococcus, Salmonella can be transmitted through the skin. Therefore food handlers should always be in health and skilled(Brata, n.d.; Halim \& Sriwahyuni, 2017).

\section{How to process food}

A good way of processing is not the occurrence of food defects as a result of wrong processing and following the rules or principles of good hygiene and sanitation or called GMP (good manufacturing practice).

\section{How to transport the food that has been cooked}

The transport of food from the treatment site to the presentation or storage needs to be given attention so as not to contaminate from insects, dust or bacteria. The container used should be intact, strong and not rusty or leaking. Transport for a long time should be set to $60 \mathrm{C}$ or cool $4 \mathrm{C}$.

\section{How to store cooked food}

Storage of cooked foods can be classified into two, food storage at regular temperatures and storage in cold temperatures. Rotting foods should be kept at a cold temperature of $<40 \mathrm{C}$. For food served over 6 hours, stored in temperature $-5 \mathrm{~s} /$ $\mathrm{d}-10 \mathrm{C}$.

\section{How to serve the cooked food}

Something that need to be considered when searching the food is that the food is protected from pollution, equipment used in good condition and clean, the officer who presents must be polite and always keep the health and cleanliness of clothes. 


\section{Food Quality}

The quality of a food product is very important for every founder of a food vendor, for example like a hotel. These quality characteristics are derived from foods that are acceptable to consumers. Food quality is an important role in consumer purchase disconnection, so it can be known if the quality of food increases, then the purchase decision will increase as well. (Margareta and Edwin 2012: 11). In producing quality food especially food in hotels must have a standard that indicates that the food has a value and quality worthy to be sold and served to hotel guests. Food quality according to Soekresno (2009: 11) has the following conditions include:

a. Many food and beverage options are provided.

b. The shape, color, taste, aroma is delicious and interesting.

c. Clean, healthy, with a balanced nutritional composition.

Food Quality Factors According to Margaretha and Edwin (2012: 11) outline the factors that affect the quality of food is as follows:

\section{Color}

The color of the ingredients should be combined in a way that does not look pale or the color does not match. Color combinations are helpful in consumer appetites.

\section{Appearance}

Food should be good to look at on a plate, which is an important factor. The freshness and cleanliness of the food served is an important example that will affect the appearance of good or not to be enjoyed.

\section{Portion}

In each food presentation has been determined standard portion called Standard Portion Size.

\section{Shape}

The form of food plays an important role in the appeal of the eye. An interesting form of food can be obtained through a variety of food cutting.

\section{Temperature}

Consumers love the variations in temperature obtained from each other's food. Temperature can also affect taste.

\section{Texture}

There are many food textures, among others, fine or not, liquid or solid, hard or soft, dry or moist. The thin and delicate levels and shape of the food can be felt through the pressure and movement of the receptor in the mouth. 


\section{Aroma}

Aroma is the reaction of foods that will affect consumers before consumers enjoy food, consumers can smell the food.

\section{Level of maturity}

The maturity level of the food will affect the texture of the food. Flavor The taste buds of the tongue is the basic detecting ability of sweet, sour, salty, bitter. In certain foods these four flavors are combined so that it becomes a unique and exciting flavor to be enjoyed.

\section{Conclusion}

\section{CONCLUSION}

The results of this study indicate that the variable storage method and food processing hygiene with sub-variables that have been described have an influence on the quality of food. This can be seen from several tests that have been done, and the results show that the variables have an influence on the quality of food. In the Personal Hygiene variable there are several things that must be considered that is the cleanliness of the self from the tip of the hair to the toe. This is influential because healthy food handlers will produce quality food as well. In Food hygiene variables there are several things that must be considered starting from the selection of foodstuffs, storage of food, processing of food, until the presentation of food.

Good food especially cakes and bread should have a quality ingredient in the clear sense of where it came from. The material storage system becomes a benchmark of foodstuffs can last long or not, either as raw materials or finished materials (in the form of baking and bread products). Good storage system that is with FIFO system (First In First Out). So that will affect the quality of food to be made. In Variable Hygiene Equipment there are several things that must be considered starting from the use of the equipment until the cleaning. This affects the quality of food to be generated because the type of material on the appliance affects the food to be made, if misused, it will cause a chemical reaction of the type of equipment used on the food being processed. In Kitchen Hygiene variables there are several elements that must be considered. As is well known that the kitchen is a place where a food handler can produce food, things to note are good kitchen conditions include floor, walls, lighting, and ventilation. A clean and good kitchen environment will produce good food quality and food tastes comfortable in processing the food.

\section{Suggestion}

1. The employees of the kitchen should pay attention to personal hygiene, work environment and food hygiene from food until the food is ready to be served with compliance with SOPs that have been established for the continuity of work going well. 
IJTI (International Journal Of Transportation And Infrastruct ure)

2. Food business owners (restaurants, depots and so on) need to organize seminars for employees, evaluating employees' work related to hygiene and sanitation.

3. Work environment conditions and working room temperature should be more attention for factors - factors that can damage the quality of food can be avoided.

4. Researchers can then conduct research by examining other variables such as hygiene and sanitation in the process of transporting until the presentation of food products.

\section{REFERENCES}

Arimbawa, I Gede, Artaya, I Putu., 2008, Penerapan Metode Korelasi dalam Mengukur Hubungan Antara Customer Relationship dengan Customer Loyalty Pada PT. Antika Raya Surabaya, Jurnal Bisnis dan Manajemen Universitas Negeri Surabaya. Vol. 1, No. 1.

Artaya, I Putu., 2018, Dasar-Dasar Manajemen Operasi dan Produksi, Narotama University Press, Surabaya.

Artaya, I Putu.,Kamisutara, Made., Baktiono, R Agus., 2018, Pengaruh Citra Produk Berdasarkan Analisis Persepsi Konsumen Pada Kelompok Usaha Aneka Pangan Di Sidoarjo, E-Jurnal Tata Sejuta STIA Mataram, Vol. 4, No. 1.

Fiani, Margaretha dan Edwin Japarianto. (2012). Analisa Pengaruh Food Quality \& Brand Image Terhadap Keputusan Pembelian Roti Kecik Took Roti Ganep"s di Kota Solo. Jurnal Manajemen Pemasaran. Universitas Kristen Petra Surabaya.

JFX Susanto S., Baktiono, R Agus, Artaya, I Putu., 2018, Optimization of governance model of post-food harest and distribution in msme centers in 5 subdistricts in sidoarjo regency, Journal of Economics, Business \& Accountancy Ventura, Vol. 20, No. 3.

Soekresno. 2009. Dasar-Dasar Pengolahan Makanan. Yogyakarta : Andi Offset.

Brata, D. P. N. (n.d.). Partisipasi Masyarakat Untuk Mewujudkan Pelayanan Publik Yang Transparan, Bebas Dari KKN dan Bertanggungjawab (Studi Kasus di Kabupaten Jombang).

Halim, P., \& Sriwahyuni, I. (2017). Patient Satisfaction Level at Local General Hospital in Mamuju Regency, Indonesia. International Journal of Science and Research (IJSR), 6(9), 1-5. Retrieved from https://pdfs.semanticscholar.org/ae7c/429df677e8c56cc18eccc5328f6692da62c $0 . p d f$ 